\title{
Pelatihan Kerajinan Manik-Manik Untuk Meningkatkan Inovasi-Kreativitas Ibu PKK Sekaligus Pendapatan UMKM
}

\author{
Slamet Fauzan ${ }^{1}$, Putri Puspitasari ${ }^{2}$, Riszki Ameliyah ${ }^{3}$ \\ ${ }^{1}$ Program Studi Pendidikan Akuntansi, Fakultas Ekonomi, Universitas Negeri Malang, Indonesia \\ ${ }^{2}$ Program Studi Administrasi Pendidikan, Fakultas Ilmu Pendidikan, Universitas Negeri Malang, Indonesia \\ ${ }^{3}$ Program Studi Pendidikan Tata Niaga, Fakultas Ekonomi, Universitas Negeri Malang, Indonesia \\ *e-mail: slamet.fauzan.fe@um.ac.id ${ }^{3}$ putri.puspitasari.1801316@students.um.ac.id ${ }^{1}$, \\ riski.ameliyah.1804116@students.um.ac.id ${ }^{2}$.
}

\begin{abstract}
Abstrak
UMKM Desa Karangan, Badegan, Ponorogo yang banyak dikelola oleh Ibu-ibu PKK masih kurang berinovasi dalam produk kerajinannya. Hal ini dapat dilihat pada produk yang dihasilkan belum ada penambahan varian produk baru. Berdasarkan hasil rapat koordinasi dengan Ibu-ibu PKK diperoleh masukan perlunya pelatihan kerajinan manik-manik untuk meningkatkan inovasi dan kreativitas produk UMKM. Pelatihan kerajinan manik-manik dilaksanakan berdasarkan ketersediaan bahan manik-manik yang mencukupi namun belum dimanfaatkan dengan baik dan rendahnya kreativitas dari warga. Untuk membantu program tersebut, dosen dan mahasiswa Universitas Negeri Malang melakukan pengabdian kepada masyarakat melalui pelatihan kerajinan manik-manik. Tujuan dari pengabdian ini untuk meningkatkan kualitas sumber daya manusia, dan meningkatkan eksistensi UMKM melalui pelatihan kerajinan manik-manik yaitu pembuatan dompet, gelang, dan pengait masker. Metode yang digunakan adalah koordinasi, pelatihan, pendampingan, rencana tindak lanjut dan refleksi. Proses pelaksanaan program kerja ini secara bertahap, berkesinambungan, dan berkelanjutan. Hasil kegiatan pelatihan kerajinan manik-manik memberikan dampak positif bahwa keseluruhan warga yang rutin mengikuti pelatihan berhasil mempraktekkannya secara mandiri, sehingga kreativitas dan inovasi menghasilkan produk kekinian dapat terwujud. Hasil wawancara pada tahap refleksi menunjukkan seluruh peserta yang awalnya tidak bisa membuat kerajinan manik-manik, setelah melalui pelatihan 100\% menjadi bisa membuat produk manik-manik yang diminati. Maka pelatihan kerajinan manik-manik ini sangat rekomendasi sebagai peningkatan kreativitas.
\end{abstract}

Kata kunci: Pelatihan kerajinan manik-manik, inovasi ibu pkk, pengabdian masyarakat

\begin{abstract}
MSMEs in Karangan Village, Badegan, Ponorogo, which are mostly managed by PKK women, still lack innovation in their craft products. This can be seen in the products produced, there has been no addition of new product variants. Based on the results of the coordination meeting with PKK women, input was obtained on the need for beading craft training to increase innovation and creativity of MSME products. Beading craft training is carried out based on the availability of sufficient beading materials but not yet used properly and the low creativity of the residents. To help the program, lecturers and students at the State University of Malang do community service through beading craft training. The purpose of this service is to improve the quality of human resources, and improve the existence of MSMEs through beading craft training, namely making wallets, bracelets, and mask hooks. The methods used are coordination, training, mentoring, follow-up plans and reflection. The process of implementing this work program is gradual, continuous, and sustainable. The results of the beading craft training activities have a positive impact that all residents who regularly attend the training successfully practice it independently, so that creativity and innovation to produce contemporary products can be realized. The results of the interview at the reflection stage showed that all participants who initially could not make beaded crafts, after going through 100\% training, became able to make beaded products of interest. So this beading craft training is highly recommended as an increase in creativity.
\end{abstract}

Keywords: Beading craft training, mother pkk innovation, community service

\section{PENDAHULUAN}

Saat ini peran serta perguruan tinggi sangat diutamakan khususnya turut serta membantu meningkatkan perekonomian masyarakat, salah satunya melalui kegiatan pengabdian masyarakat. Pengabdian masyarakat ini sebagai abdi pelaksanaan Tri Dharma 
Perguruan Tinggi, yang wajib dilakukan oleh para dosen dan mahasiswa[1]. Pengabdian yang dilakukan saat ini berupa pelatihan untuk meningkatkan motivasi berkreativitas dan inovasi untuk kualitas keanekaragaman hasil UMKM secara konsentrasi[2]. Pengabdian dilaksanakan oleh dosen sebagai pembimbing dengan beberapa anggota yaitu mahasiswa pada Desa Karangan, Kecamatan Badegan, Kabupaten Ponorogo.

Desa Karangan, Kecamatan Badegan, Kabupaten Ponorogo merupakan desa yang memiliki visi merubah tatanan masyarakat menjadi masyarakat yang kreatif dan inovatif untuk mendukung mewujudkan desa wisata yang memiliki sejuta potensi di dalamnya. Mayoritas penduduk di Desa Karangan ini hampir 75\% bermata pencaharian sebagai petani, sehingga sumber penghasilan berasal dari hasil berkebun atau persawahan. Berdasarkan latar belakang tersebut tentunya membuat masyarakat mempunyai tingkat keterampilan dan inovasi yang kurang dalam mengembangkan suatu usaha. Kebanyakan warga masyarakat hanya memproduksi barang-barang tertentu saja dan masih membutuhkan banyak perbaikan dan pengembangan. Hasil produk UMKM masih perlu ditingkatkan dan membutuhkan inovasi dan kreativitas dari keanekaragaman produk sesuai dengan peminatan dan potensi dari pelaku usaha di masyarakat.

Di masa pandemi Covid-19 seperti saat ini, masyarakat desa karangan sangat merasakan dampak dari adanya Covid-19 ini. Masyarakat merasakan dampak yang sangat besar karena tidak dapat bekerja dan beraktivitas diluar rumah secara bebas. Banyak diantara mereka yang harus menghemat karena tidak mendapatkan pemasukan. Dampak kondisi perekonomian rumah tangga sangat dirasakan bagi kepala keluarga yang harus dirumahkan. Hal ini tentunya berpengaruh pada terhambatnya keuangan keluarga. Menindaklanjuti kendala tersebut, masyarakat harus berupaya untuk mengatasi dampak adanya Covid-19 tersebut dengan menambah penghasilan keluarga melalui kegiatan yang produktif dengan berwirausaha. Salah satu cara untuk berwirausaha adalah dengan memberikan pengetahuan dan keterampilan berwirausaha.

Berdasarkan hasil observasi yang telah dilakukan selama 20 hari memberikan gambaran bahwa di Desa Karangan terdapat beberapa UMKM seperti budidaya kelinci, peternakan kambing, tas anyaman, cacing lumbricus, dan mebel. UMKM yang ada di Desa Karangan tersebut hanya ada di beberapa tempat saja dan merupakan usaha milik pribadi, bukan usaha milik organisasi. Hal tersebut tentunya menjadi penghambat tercapainya visi dan misi Desa Karangan untuk membangun desa menjadi desa wisata. Pada saat ini, upaya mewujudkan desa karangan menjadi desa wisata masih belum bisa berjalan karena terhambat beberapa kendala. Kendala tersebut diantaranya adalah kurangnya edukasi kepada masyakarat terkait dengan produktivitas daerah untuk menghasilkan produk baru dan bisa dikembangkan menjadi produk yang berkualitas dan bernilai jual tinggi. Selain itu masyarakat juga kurang memahami peluang usaha dan hanya bekerja sesuai kemampuannya saja seperti menggarap sawah dan kebun. Sehingga UMKM yang perlu dilakukan adalah menghasilkan produk kreatif dan inovatif yang terbuat dari bahan-bahan yang mudah didapatkan dengan harga terjangkau[3].

Berdasarkan hasil wawancara dengan kepala desa, masyarakat desa Karangan memiliki antuasiasme yang tinggi terhadap kegiatan-kegiatan yang sekiranya bermanfaat untuk peningkatan perekonomian desa, dan banyak warga memiliki potensi tinggi namun belum diperdayakan atau dilatih dengan benar selama ini, sehingga UMKM di desa ini tidak berkembang kearah produk-produk kekinian. Oleh karena itu, program kerja pengabdian dosen dan mahasiswa di desa Karangan disesuaikan dengan permasalahan desa yaitu kurangnya edukasi dan pelatihan untuk membentuk masyarakat yang produktif, kreatif dan inovatif. Pihak desa mensiasati kendala tersebut dengan memberikan bantuan pada setiap dukuh untuk dimanfaatkan sebagai modal membuka usaha. Modal tersebut diberikan secara merata pada setiap dukuh di Desa Karangan. Akan tetapi, usaha yang dijalankan dari modal tersebut hanya dijalankan saja dan tidak dikembangkan untuk lebih luas lagi dan akhirnya diambil alih menjadi usaha perseorangan atau usaha pribadi. Melihat visi desa wisata maka dipilihkan produk berupa dompet, gelang, dan pengait masker dari manik-manik. Seperti yang diketahui, dompet merupakan jenis barang yang banyak diminati di semua kalangan 
masyarakat saat ini, karena hampir setiap hari warga membutuhkan dompet untuk menyimpan uang atau kartu penting lainnya. Dompet juga dapat digunakan baik acara formal atau non formal. Dompet dimasa kini yang rival salah satunya terbuat dari manik-manik. Tidak terbatas pada dompet saja, manik-manik juga dapat digunakan untuk membuat pengait masker dan gelang untuk pendukung penampilan. Apalagi kondisi saat ini masih pandemi covid 19 masyarakat sangat membutuhkan pengait masker untuk digunakan sebagai pengganti tali masker jenis hijab, gelang juga dibutuhkan saat ini sebagai souvenir atau merchandise[4]. Melihat kondisi saat ini yang memasuki era peningkatan kebutuhan milenial, tentu segala produk unik akan mendapat nilai lebih dari masyarakat[5]. Salah satu kerajinan yang populer saat ini yaitu berasal dari manik-manik, sebab selain warna yang beragam, ukuran dan jenis manik-manik juga mempengaruhi keindahan hasil produknya[6]. Menghasilkan produk demikian, perlu membentuk kreativitas dan inovasi dari warga desa Karangan.

Kreativitas sangat diperlukan saat ini di era milenial, untuk mengetahui segala peluang dalam memanfaatkan atau menjadikan sesuatu untuk perkembangan perekonomian yang berbeda dari sebelumnya[7]. Perlu diketahui kondisi warga adalah: (1) berkeinginan menghasilkan produk masa kini yang berharga jual tinggi, namun tidak mengetahui cara pembuatannya, dan (2) belum pernah dilakukan kegiatan pelatihan secara khusus cara membuat benda dengan teknik manik-manik. Berdasarkan permasalahan tersebut, pelaksanaan pelatihan kerajinan manik-manik pembuatan dompet, gelang, dan pengait masker ini dapat memberikan solusi yang tepat dan sesuai harapan harapan masing-masing warga. Warga Desa Karangan hampir keseluruhan membutuhkan pelatihan-pelatihan yang dapat bermanfaat sampai berkelanjutan, melalui pelatihan manik-manik dapat membentuk ketelatenan, kesabaran dalam menyusun pola, dan memunculkan ide untuk menentukan model produk unik yang akan dihasilkan. Target luaran yang diharapkan dari pelatihan kerajinan manik-manik di Desa Karangan untuk masing-masing peserta adalah: (1) peserta memiliki keterampilan menyusun pola pembuatan dompet, gelang, dan pengait masker (2) penerapan berbagai metode pembuatan dari persiapan hingga penyelesaian, sampai jadi produknya berupa dompet, gelang, dan pengait masker (3) mampu menghasilkan produk kerajinan manik-manik berbagai jenis, bentuk, dan warna.

Berdasarkan hasil penelitian sebelumnya, pengabdian ini dilakukan dengan pendekatan pasrtisipatif untuk melihat dampak dari pelatihan kerajinan tangan berupa manik-manik untuk mendorong meningkatkan motivasi dan kreativitas serta inovasu terhadap hasilnya sehingga mendukung pembentukan UMKM khususnya kerajinan tangan dari manik-manik berupa dompet, gelang, dan pengait masker. Berdasarkan penjelasan tersebut, tujuan pengabdian dosen dan mahasiswa di desa Karangan melalui pelatihan kerajinan manik manik adalah: (1) untuk membentuk dan meningkatkan kreativitas serta inovasi warga dalam menghasilkan produk kekinian dengan bahan manik-manik, (2) mendukung hasil UMKM berupa produk masa kini sehingga berdampak pada kesejahteraan masyarakat, (3) mendukung nilai produktivitas berupa ciri khas desa akan terwujudnya desa wisata.

\section{METODE}

Pelaksanaan pengabdian dosen dan mahasiswa melalui pelatihan kerajinan manikmanik, dilaksanakan di Desa Karangan, Kecamatan Badegan, Kabupaten Ponorogo setiap hari Sabtu dengan tujuh kali pertemuan. Pelatihan kerajinan manik-manik dimulai tanggal 12 Juni sampai 24 Juli 2021. Partisipasi dalam kegiatan pelatihan kerajinan manik-manik adalah sekumpulan ibu PKK dengan alasan sebagai perwakilan setiap dukuh untuk disalurkan hasil pelatihan nantinya serta memenuhi protokol kesehatan covid-19 yaitu pembatasan sosial [8]. Alat dan bahan yang dibutuhkan hanyalah senar, butir manik-manik dengan jumlah dan ukuran yang ditentukan sesuai kebutuhan/selera, dan gunting untuk menggunting tali senar yang diperlukan untuk membentuk. Adapun media yang digunakan adalah mangkuk sebagai 
wadah manik-manik agar penyusunan pola manik-manik benar dan rapi. Metode yang digunakan dari kegiatan pelatihan pembuatan dompet, gelang, dan pengait masker yakni: 1) Koordinasi dengan ibu PKK sebagai langkah awal guna mendapatkan informasi dan mengetahui antusiasisme dalam kegiatan; 2) Penjelasan alat, cara pembuatan, dan penjelasan langkah-langkah pembuatan produk yang akan dihasilkan untuk mendukung minat dari ibu PKK; 3) Pelaksanaan pelatihan kerajinan manik-manik bersama ibu PKK sesuai dengan produk yang akan dihasilkan; 4) Pendampingan membuat kerajinan dari manik-manik; 5) Pembuatan catatan hasil pendampingan pelatihan kepada ibu PKK, untuk menganalisis pemecahan masalah yang dihadapi, dan terus dimobitor perkembangan setiap pelaksanaan kegiatan; dan 6) refleksi dengan melihat dampak, umpan balik, atau pengaruh dari pelatihan. Sedangkan tata cara pembuatan kerajinan dari manik-manik sebagai berikut:

1. Persiapkan senar dan gunting sebagai alat dan bahan dasar. Memasukkan manikmanik dalam mangkuk atau tempat lain yang mudah dijangkau. Gunting senar dengan panjang 1 meter. Kemudian ingat pola memasukkan manik-manik dalam senar. Pola pertama masukkan tiga manik-manik sekaligus, kemudian masukkan satu manik untuk kunci pola pertama

2. Kunci manik-manik ini dengan memasukkan senar secara bersilangan. Kemudian pola kedua memasukkan satu manik kiri, satu manik kanan, kemudian kunci. Ulangi poin ketujuh sampai panjang yang diinginkan, apabila menempati pola terakhir yaitu menyusun lebar, maka

3. Kunci manik-manik dikiri dan masukkan dua manik sebelah kanan, lalu masuk satu kiri untuk kunci, kemudian ulangi pola sampai membentuk produk yang dinginkan. Jika menghasilkan dompet membutuhkan panjang $9 \mathrm{~cm}$ x lebar $18 \mathrm{~cm}$ dengan 64 pola. Gelang panjang kira-kira $8 \mathrm{~cm}$ dengan 1 pola. Sedangkan pengait masker panjang antara $10 \mathrm{~cm}$ sampai $20 \mathrm{~cm}$ dengan 1 pola.

\section{HASIL DAN PEMBAHASAN}

Kegiatan pengabdian masyarakat yang dilakukan dengan memberikan pelatihan pembuatan dompet dari manik-manik ini diawali dengan kegiatan perkenalan bersama ibuibu PKK Desa Karangan, Badegan, Ponorogo. Kegiatan perkenalan ini dilakukan untuk memperkenalkan anggota tim Pengabdian yang bertanggungjawab sebagai pelatih pembuatan dompet dari manik-manik dan juga mengedukasi masyarakat mengenai kerajinan manikmanik yang akan dilaksanakan beberapa waktu ke depan bersama ibu-ibu PKK Desa Karangan, Badegan, Ponorogo. Berdasarkan kegiatan perkenalan tersebut dapat diketahui bahwa minat ibu-ibu terhadap pelatihan kerajinan manik-manik ini cukup tinggi. Banyak ibu-ibu yang tertarik dan ingin segera membuat kerajinan dari manik-manik. Mengingat manik-manik merupakan bahan kerajinan yang mewah, mudah didapatkan dengan harga terjangkau [9]. Maka melalui kegiatan perkenalan tersebut, tim Pengabdian di Desa Karangan juga mengajak ibu-ibu berdiskusi untuk menentukan produk yang akan dibuat. Kegiatan diskusi yang dilakukan memperoleh hasil bahwa ibu-ibu PKK menginginkan produk berupa dompet dan strap mask dua fungsi yaitu dapat digunakan sebagai gelang dan pengait masker.

Setelah melakukan kegiatan perkenalan, kegiatan dilanjutkan dengan dua cara yaitu secara daring dan tatap muka, artinya pelaksanaan secara bergantian. Kegiatan pelatihan menggunakan dua model tersebut dilakukan dengan tujuan untuk mengurangi kegiatan berkerumun dengan masyarakat untuk mencegah penyebaran virus Covid-19 [10]. Kegiatan pelatihan dengan model daring dilakukan dengan membentuk grup bersama ibu-ibu PKK yang dilanjutkan dengan memberikan video simulasi atau video tutorial pembuatan dompet dari manik-manik. Kegiatan dengan model daring dilaksanakan pada tanggal 19 Juni 2021 sudah berjalan dengan baik namun masih terdapat beberapa kendala dalam pelaksanaannya. Kendala tersebut di antaranya adalah ibu-ibu kurang antusias jika pelatihan dilakukan dengan model daring dan ibu-ibu juga tidak bisa memahami proses pembuatan dompet jika tidak dipraktikkan secara langsung. 
Berdasarkan kendala yang ada, tim Pengabdian memutuskan untuk memberikan pelatihan secara tatap muka atau langsung dengan mematuhi protokol kesehatan. Kegiatan pelatihan dibatasi dengan jumlah 15 orang saja. Kegiatan tatap muka dilaksanakan di Posko KKN Desa Karangan. Kegiatan pelatihan yang dilaksanakan dengan model tatap muka dapat berjalan dengan lancar. Ibu-ibu sangat antusias saat melaksanakan kegiatan pelatihan dan mau belajar lebih banyak lagi mengenai kerajinan dari manik-manik. Dalam pelaksanaannya ada beberapa ibu-ibu yang terhambat dalam belajar dikarenakan penglihatan yang berkurang, namun hal tersebut tidak mengurangi rasa semangat belajar dari ibu-ibu untuk membuat kerajinan dari manik-manik.

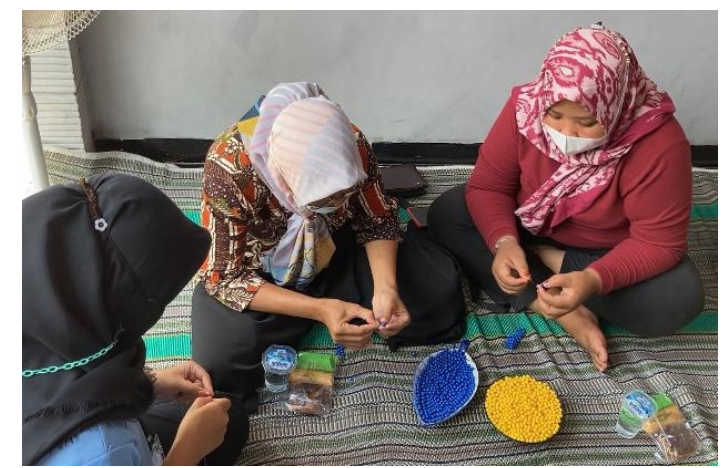

Gambar 1. Proses pelatihan pembuatan dompet dari manik-manik

Tim Pengabdian memberikan pelatihan dan pendampingan kepada Ibu-ibu PKK di Desa Karangan secara berkelanjutan. Kegiatan pelatihan kerajinan manik-manik dilaksanakan setiap satu minggu sekali pada hari Sabtu. Pelatihan ini dilaksanakan selama 7 kali pertemuan selama kegiatan pengabdian berlangsung.

Tabel 1. Jadwal Kegiatan Pelatihan Kerajinan Manik-Manik

\begin{tabular}{|c|c|c|c|}
\hline No. & Hari/ Tanggal & Waktu Pelatihan & $\begin{array}{ll}\text { Pelatihan } \\
\end{array}$ \\
\hline 1 & Sabtu, 12 Juni 2021 & 08.30-10.30 WIB & $\begin{array}{c}\text { Perkenalan Tim Pengabdian } \\
\text { bersama Ibu-ibu PKK }\end{array}$ \\
\hline 2 & Sabtu, 19 Juni 2021 & 08.30-10.30 WIB & $\begin{array}{l}\text { Penayangan Video Tutorial } \\
\text { Pembuatan Dompet dari Manik- } \\
\text { manik melalui Grub WhatsApp }\end{array}$ \\
\hline 3 & Sabtu, 26 Juni 2021 & 08.30-10.30 WIB & $\begin{array}{l}\text { Pelatihan Kerajinan Manik-manik } \\
\text { tahap satu (Membuat pola sisi } \\
\text { memanjang) }\end{array}$ \\
\hline 4 & Sabtu, 3 Juli 2021 & 08.30-10.30 WIB & $\begin{array}{c}\text { Pelatihan Kerajinan Manik-manik } \\
\text { tahap dua (Membuat pola sisi } \\
\text { lebar) }\end{array}$ \\
\hline 5 & Sabtu, 10 Juli 2021 & 08.30-10.30 WIB & $\begin{array}{l}\text { Pelatihan Kerajinan Manik-manik } \\
\text { tahap tiga (Menggabungkan dua } \\
\text { sisi dompet) }\end{array}$ \\
\hline 6 & Sabtu, 17 Juli 2021 & 08.30-10.30 WIB & $\begin{array}{l}\text { Pelatihan Kerajinan Manik-manik } \\
\text { tahap penyelesaian (Membuat } \\
\text { tali dan tutup dompet\} }\end{array}$ \\
\hline 7 & Sabtu, 24 Juli 2021 & 08.30-10.30 WIB & $\begin{array}{l}\text { Pelatihan Kerajinan Manik-manik } \\
\text { membuat Strap Mask dua fungsi }\end{array}$ \\
\hline
\end{tabular}

Hasil yang diperoleh dari kegiatan pelatihan kerajinan manik-manik ini adalah terciptanya hasil karya seni yang memiliki nilai estetika tinggi khususnya kerajinan manikmanik dalam bentuk dompet dan strap mask dua fungsi oleh ibu-ibu PKK di Desa Karangan, 
Badegan, Ponorogo. Pelaksanaan kegiatan ini sudah berjalan lancar sesuai dengan yang diharapkan. Peserta terlihat antusias dalam mempelajari cara membuat kerajinan dari manikmanik. Pengetahuan ibu-ibu terkait kerajinan manik-manik menjadi bertambah baik dan ibuibu menjadi memiliki nilai kreativitas yang tinggi. Kesadaran ibu-ibu untuk memanfaatkan waktu luang menjadi bertambah dan akan dimanfaatkan untuk membuat kerajinan dari manik-manik. Pelatihan dilaksanakan semaksimal mungkin agar ibu-ibu dapat menguasai teknik-teknik dan pola yang dibutuhkan untuk membuat kerajinan dari manik-manik [11]. Hal ini dilakukan dengan harapan bahwa ibu-ibu yang sudah diberikan pelatihan dapat menyalurkan ilmunya kepada anggota lain yang belum berkesempatan mengikuti kegiatan pelatihan kerajinan manik-manik.

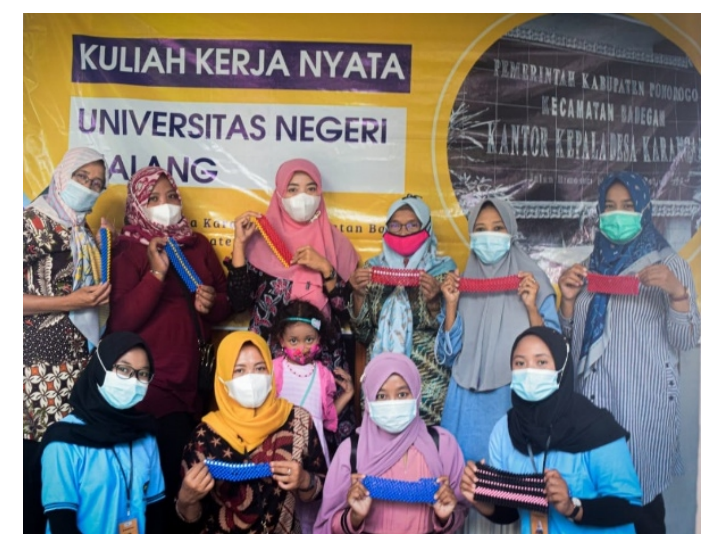

Gambar 2. Hasil pembuatan dompet dari manik-manik

Dari rangkaian kegiatan pengabdian pada masyarakat yang telah dilaksanakan dalam bentuk pelatihan ini, maka ibu-ibu PKK yang menjadi sasaran dalam program kerja ini dapat memperoleh hasil yaitu pengetahuan dan keterampilan untuk membuat kerajinan. Melalui pelatihan ini, ibu-ibu dapat termotivasi untuk memanfaatkan waktu luang melalui kegiatan yang produktif. Pada dasarnya produktif diawali dari adanya kegiatan unik yang dapat menarik minat, dan memberikan hasil yang menjanjikan [12]. Mendorong untuk kegiatan keberlanjutan pelatihan membuat kerajinan dari manik-manik ini, tim pengabdian menyediakan video simulasi atau tutorial dalam bentuk video yang sudah dibuat khusus untuk ibu-ibu PKK sebagai acuan apabila tim pengabdian sudah tidak bisa melakukan pendampingan bersama ibu-ibu PKK. Melalui pelatihan ini diharapkan dapat membantu ibu-ibu PKK mendapatkan penghasilan tambahan meskipun harus bekerja dari rumah seperti saat ini. Pada tahap akhir pengabdian yaitu tahap refleksi. Tim pengabdian melakukan wawancara terkait seberapa besar prosentase peserta dalam menguasai materi peatihan. Hasil dari wawancara terhadap semua peserta dipeoleh hasil 100\% peserta menguasai materi pelatihan dan dapat mempraktekannya.

\section{KESIMPULAN}

Kegiatan pengabdian kepada masyarakat yang dilakukan oleh dosen dan mahasiswa memberikan pengaruh terhadap peningkatan motivasi, inovasi dan kreativitas warga desa melalui perwakilan ibu PKK. Antusias peserta pelatihan memberikan dampak positif terhadap keberhasilan pelaksanaan kegiatan, hal ini dikarenakan adanya harapan peserta latihan untuk mendirikan UMKM dengan hasil produk berupa kerajinan tangan dari manik-manik. Tentu dapat meningkatkan kesejahteraan masyarakat, dan mendukung provit desa wisata. Peningkatan kualitas hasil produk kerajinan tangan berupa manik-manik akan lebih maksimal dilakukan secara terus menerus tidak terbatas waktu dan berkelanjutan dengan menghasilkan produk-produk yang berbeda. Diharapkan produk hasil pelatihan memberikan nilai lebih tinggi dari produk berbahan lainnya dan mampu untuk dipasarkan seluasseluasnya. Pada program pengabdian masyarakat di waktu yang akan datang, dapat 
memfokuskan pada peningkatan kerja sama dengan mitra usaha dan pelaku industri untuk mendukung keaneka ragaman produk kerajinan tangan, serta membantu pemasaran produk pada ranah nasional dan membentuk UMKM baru khususnya kerajinan tangan berbahan manik-manik. Hasil dari pelatihan ini peserta $100 \%$ dapat membuat produk kerajinan manikmanik setelah mengikuti pelaihan, hasil ini terlihat dari wawancara pada kepada seluruh peserta pada tahap refleksi.

\section{UCAPAN TERIMA KASIH}

Terimakasih disampaikan atas terlaksananya kegiatan pengabdian ini kepada: Universitas Negeri Malang yang telah memberikan kesempatan dan bantuan untuk pelaksanaan pengabdian kepada masyarakat ini. Kepala desa Karangan, Kecamatan Badegan, Kabupaten Ponorogo Bapak Pujianto yang telah mengizinkan pelaksanaan pengabdian dosen dan mahasiswa, serta mendukung pelaksanan kegiatan pelatihan manik-manik mulai dari persiapan sampai penutupan kegiatan ini. Perangkat desa Karangan yang telah membantu mempersiapkan tempat untuk pelaksanaan pengabdian dan memberikan pengarahan untuk mengumpulkan ibu PKK. Mitra usaha tas anyaman desa Karangan yang telah memberikan izin untuk meliput, observasi, dan mendukung dalam mempelajari teknik menganyam, sehingga dapat menyesuaikan kualitas pelatihan kerajinan manik-manik yang seimbang dengan kualitas tas anyaman tersebut. Serta seluruh ibu PKK yang bersedia mengikuti pelatihan kerajinan manik-manik untuk disalurkan dan dilatihkan kepada seluruh warga desa Karangan.

\section{DAFTAR PUSTAKA}

[1] R. I. Chandravialissa and E. Zulaikha, "Pengembangan Desain Kerajinan Manik-Manik Kaca sebagai Tas Wanita," J. Sains dan Seni ITS, vol. 7, no. 1, pp. 7-10, 2018, doi: 10.12962/j23373520.v7i1.29436.

[2] D. Diana, M. A. Adriansyah, M. Muhliansyah, and A. P. Putri, "Pelatihan manik khas dayak dalam meningkatkan konsentrasi," Plakat (Pelayanan Kpd. Masyarakat), vol. 1, no. 1, p. 17, 2019, doi: 10.30872/plakat.v1i1.2691.

[3] E. PUTRI HIDAYATI, "Pengaruh Modal Kerja Dan Strategi Pemasaran Terhadap Keberhasilan Usaha Kerajinan Manik-Manik Kaca Desa Plumbon Gambang Kecamatan Gudo Kabupaten Jombang," J. Pendidik. Ekon., vol. 4, no. 3, 2016.

[4] J. Ilmiah, E. Dan, and A. Info, "MENINGKATKAN VOLUME PENJUALAN PADA UMKM GRIYA MANIK DI DESA PLUMBON JOMBANG," vol. 13, no. 2, pp. 21-30, 2020.

[5] H. J. P. Harahap, "IbM Peningkatan Pendapatan Ibu-ibu PKK Melalui Pembuatan Kerajinan Manik-manik," J. Pengabdi. Kpd. Masy., vol. 19, no. 73, pp. 73-77, 2013.

[6] D. I. Galeri, G. Manik, and G. Jombang, "Pengembangan Desain Kerajinan Manik-Manik Kaca," vol. 04, pp. 533-537, 2016.

[7] S. R. Dewi, A. Andari, and M. R. Masitoh, "Peran Pelatihan Dan Workshop Bagi Peningkatan Motivasi, Inovasi Dan Kreativitas Pada Umkm Kerajinan Tangan Dari ManikManik," Kaibon Abhinaya J. Pengabdi. Masy., vol. 1, no. 2, p. 59, 2019, doi: 10.30656/ka.v1i2.1509.

[8] B. Ibu, I. B. U. Pkk, and K. Banjarsari, “114 RT sehingga," vol. 33, no. 01, pp. 133-146, 2021.

[9] A. M. Ulfa, P. Suharso, and Sukidin, "Peran buruh wanita pengrajin manik-manik di desa ledokombo kecamatan lekodombo kabupaten jember," vol. 15, pp. 162-171, 2021, doi: 10.19184/jpe.v15i1.21321.

[10] Ratnaning, "Pengabdian Integritas : Jurnal Pengabdian," Pengabdian, vol. 4, no. 1, pp. 1-12, 2020.

[11] M. M. Ayu Fitri, Budi Rismayadi, "PELATIHAN KEWIRAUSAHAAN TENTANG BISNIS RUMAHAN BAGI KECAMATAN RENGASDENGKLOK KAB KARAWANG Ayu Fitri , Budi 
Rismayadi , Mumun Maemunah," BERNAS J. Pengabdi. Kpd. Masy., vol. 1, no. 1, pp. 22-31, 2020.

[12] Dewi Surani, Listiawati, Merli Andini, and Naufal Mahdy, "Pelatihan Macrame Untuk Meningkatkan Keterampilan Ibu-Ibu Rumah Tangga Produktif Di Lingkungan Kelurahan Dalung," J. Abdimas Bina Bangsa, vol. 1, no. 2, pp. 143-152, 2020, doi: 10.46306/jabb.v1i2.12. 